\title{
The Castle of Mussomeli (CL) and its Stables: an Educational and Connecting Space between Local Historical Heritage Sites
}

\author{
Mariateresa Galizia \\ Graziana D'Agostino \\ Andrés Payà Rico \\ Giuseppe Maria Spera
}

Abstract

The study aims to propose innovative and partipatory methodologies for the creation of paths of learning, communication and fruition of cultural heritage adapted to the profiles of various types of users. The object of this study is the town of Mussomeli, a Sicilian municipality in the province of Caltanissetta. Many foreign and local groups of tourists and students visit the town to admire the splendid architecture of the Manfredonico castle and its high cultural heritage. The manor, built in I 300 by Manfredi III of Chiaramonte, is the main attraction, and the fortification and its stables have therefore become the focal point for the dissemination and appreciation of the territory's rich history. Through the use of digital technologies and innovative languages of communication, the study aims to propose cultural and learning itineraries in the stables that will promote interest in the architectural and artistic heritage of the town. This study also to mitigate certain space-time, social, cultural and generational 'distances', with the ultimate goal of involving and educating visitors through pedagogical strategies and digital approaches to culture and inspire them to respect and preserve such treasures.

Keywords

digital survey, educational languages, storytelling, cultural heritage, virtual fruition.

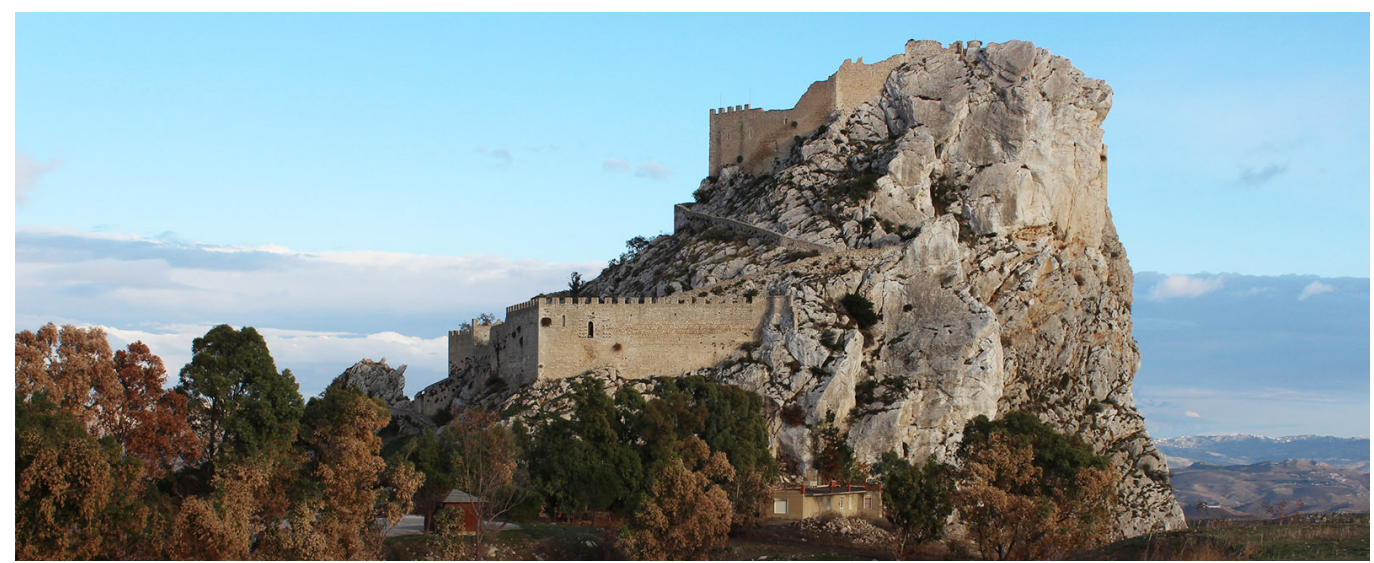




\section{Introduction}

This paper proposes the experimentation of the workflow surrounding an educational and pedagogical project, including dissemination, conducted as part of a doctorate carried out in collaboration with the Department of Comparative Education and History of Education - University of Valencia. The aim is to communicate site cultures through pedagogical strategies that intersect users across social, cultural and generational spans, supported by the use of digital technologies [Galizia et al. 2020; Martínez Gil, Santacana 2018]. The idea of instilling cultural heritage with an educational and formative role that foments a growing sense of belonging through the recognition of common cultural tradition was heavily promoted in the the Faro Convention, in 20 15. Territories, towns and villages should be places of informal learning with a strategic role in a perpetual formative process that is developed over a lifelong learning framework [Balconi, Fredella, Nigris, Zecca 20 I7]. In this perspective, the lesser-known historical centre of Mussomeli and part of its architectural and religious-artistic heritage form the basis of the case study under examination. As the Manfredonico castle is the most important cultural attraction in the area, it represents an opportune conduit for raising awareness of the historical significance of the town centre and the entire cultural and historical heritage of the area (fig. I). Specifically, its stables represent an ideal educational space for communicating, presenting and exhibiting religious architecture and its artistic heritage through various media, including display panels, videos, and multimedia stations for viewing $3 \mathrm{D}$ models. The educational and pedagogical strategy targets primary and secondary school students and tourists as the principal audiences, who shall be offered different participatory routes for absorbing the various historical, artistic, architectural and religious themes. The exploration of the digital contents displayed in the stables should ultimately stimulate a desire to visit the historic centre of Mussomeli in person. At the same time, the town becomes an 'open-air museum', in which the local architecture showcases its artistic heritage.

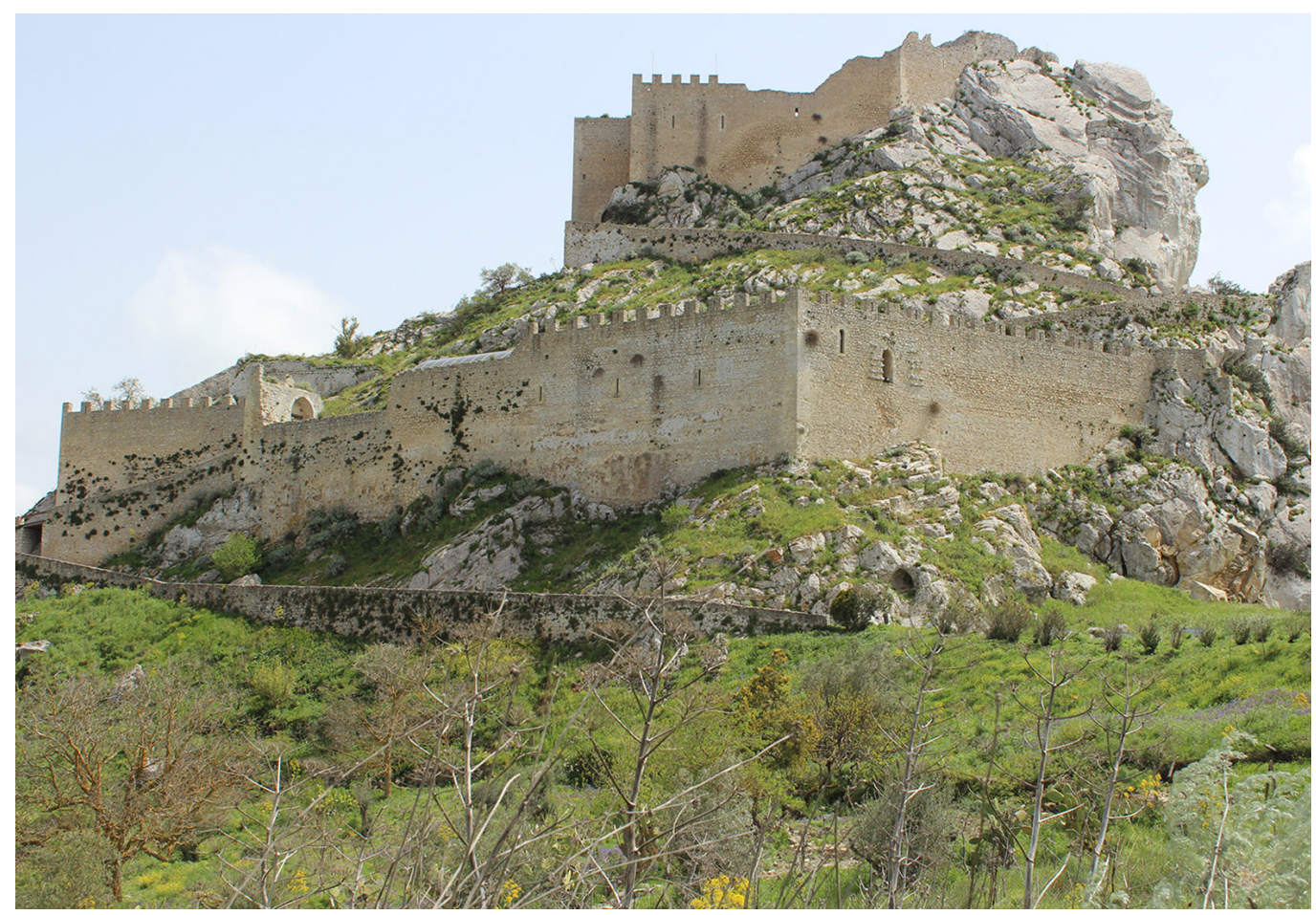




\section{The educational role of Mussomeli's architectural and artistic religious heritage}

Schools are pivotal in imparting knowledge that stimulates cultural awareness in students, and it is imperative to ensure knowledge is always evolving and close to the learner's world and spheres of interest [Andreassi, Barausse, D'Alessio 20 I6; Martínez Gil 20 I 4]. In this context, cultural heritage and technological innovations aimed at learning and using heritage can encourage young people to consolidate and share their understanding of their surrounding culture.

The objectives of the proposed methodology are to outline an educational model applied to cultural heritage that are able to:

- involve a wide public so that tangible and intangible knowledge of heritage can be more widely disseminated as far as the social and cultural layers that are generally less inclined to engage with such offerings [Martínez Gil 20 I5];

- attract younger generations to cultural heritage through technological innovations applied to documentation, knowledge and creative storytelling processes;

- increase the sense of belonging to the cultural heritage through the study of the characteristic elements that connect locals with their past;

- establish partnerships between schools, universities, public administrations and cultural institutions;

- design cognitive paths of 'diffuse heritage' so that the new generations and citizens can interact with and appreciate the territory.

The proposed educational model is based on a participatory learning approach [Payà 20 I 4] in which the subject is profoundly engaged by combining two approaches: I) visiting the building in situ; 2) using remote technological support.

Fig. 2. Stables of the Manfredonico Castle in Mussomeli (CL), I4 Century.

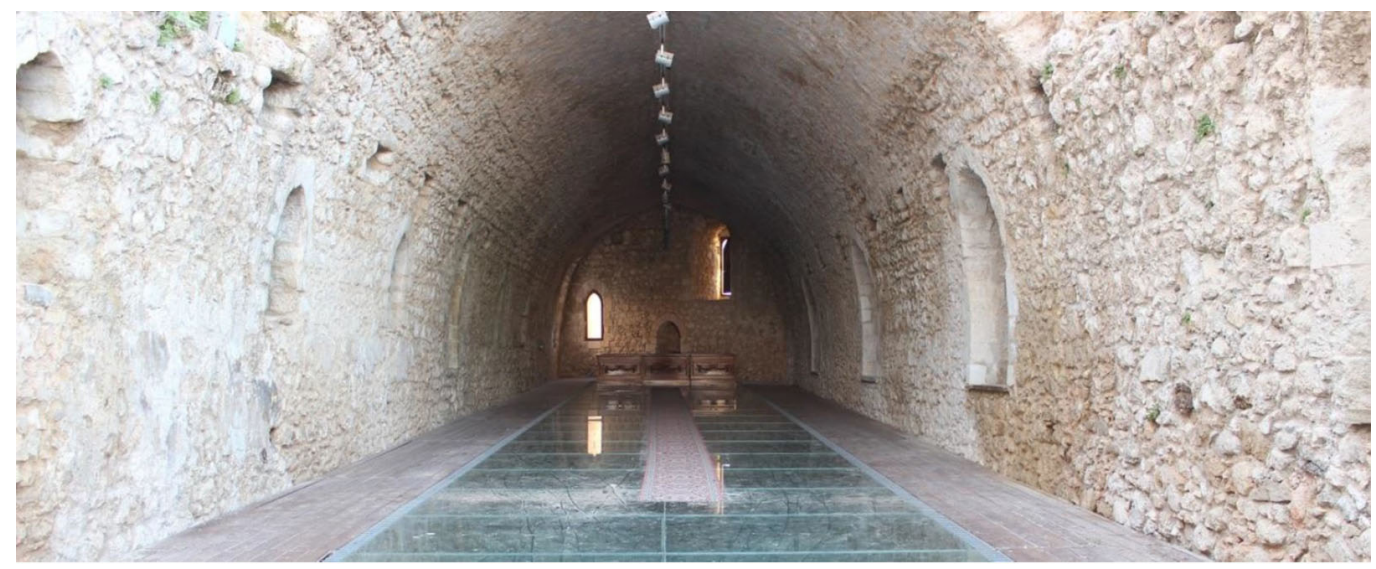

\section{Methodology}

The proposed methodology involves the experimentation of innovative teaching strategies aimed at the comprehension, narration and virtual and immersive fruition of the religious architectures and their artistic heritage located in the historical city centre. The research is based on a participatory approach in which the student or adult directs their own development and learning [I]. The profiles of two categories of users have been identified to form the criteria around which the project is developed: I) primary and secondary school students (6-13, I3-18 years old); 2) tourists (families and/or groups). 
The envisaged activities include:

- identification of historical/architectural heritage to be reproduced;

- deepening appreciation of heritage through documentation, bibliographic, archival and iconographic research;

- integrated digital survey (Laser Scanner and Structure from Motion - SfM) of the religious buildings and the artistic heritage, as well as the creation of explorable and accessible digital models;

- two-dimensional graphic representations of heritage (plans, elevations, sections), obtained from digital models;

- graphic design of exhibition panels revealing religious architecture and artistic heritage and immersive experiences using low-cost VR technologies triggered by QR-codes;

- on-site workshop activities according to age range, designed to involve users in a participatory process: workshops and creative activities aimed at developing curiosity, observation skills, intuition and creativity through play, storytelling and sensorial experiences (painting and drawing, plastic models, puzzles, ceramics, treasure hunts, etc.).

The project of education and dissemination from the castle stables will use contemporary communication channels to stimulate the curiosity and the involvement of users and inspire in situ visits of historical and cultural heritage sites. [Ferrari 20 I7; Scandurra 2018].

Fig. 3. The historical urban layout of Mussomeli

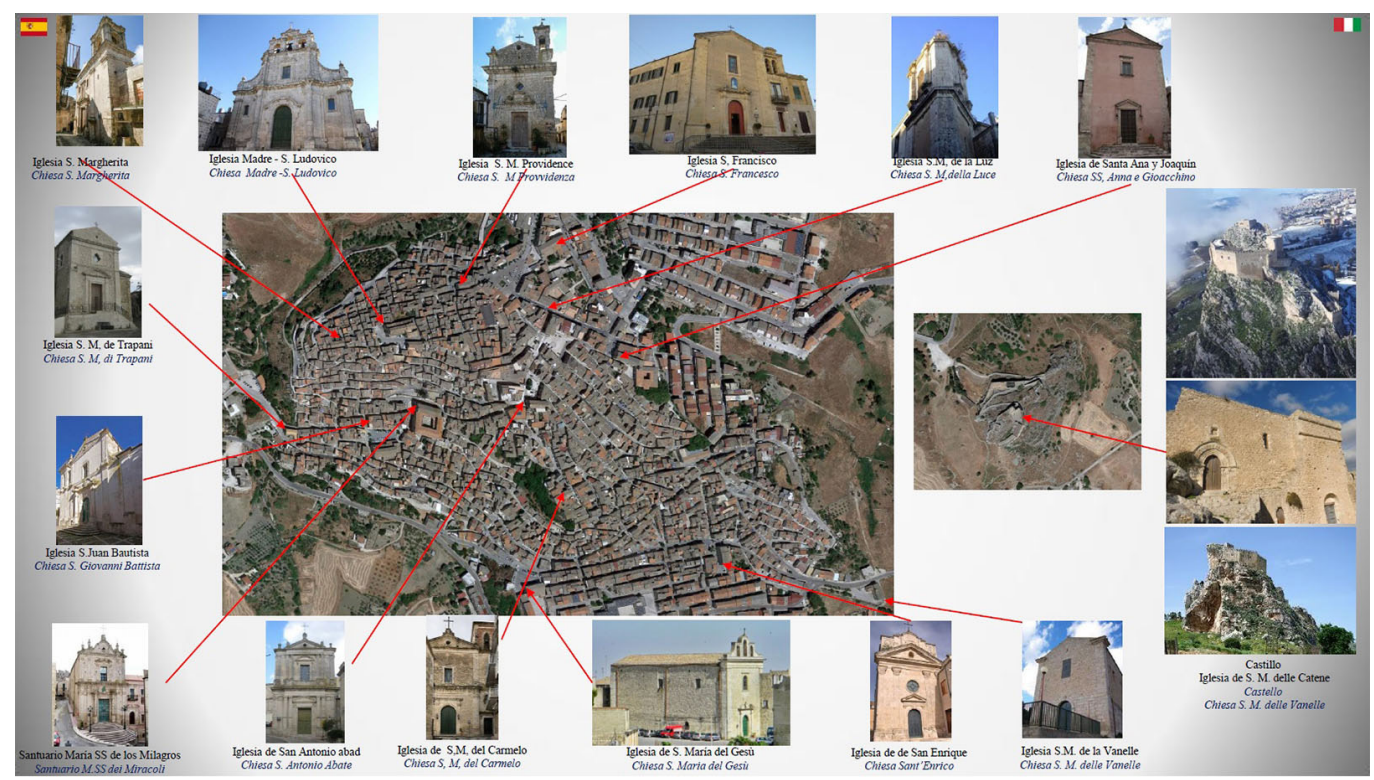

\section{The case study}

The use of contemporary technology makes it possible to visit distant or unknown places, and create virtual digital experiences that ultimately motivate real visits in person. The structures involved in the proposed experience were chosen for their architectural relevance, cultural content and, above all, pertinence to the local populations. The castle stables along with the Sanctuary of the Madonna dei Miracoli represent the first case studies for applying the methodology to the discovery of the territory of Mussomeli.

The castle has a dual role as both as main attraction and exhibition site, with its stables forming a space for education and dissemination of digital content surrounding the local cultural heritage. The Sanctuary of the Madonna dei Miracoli, on the other hand, is a prime example of the religious architecture to be visited for its architectural beauty and wealth of sacred artistic heritage it contains. 
The castle of Mussomeli and its stables: the educational role of the architectural/artistic heritage between real and virtual fruition

Between I 364 and 1367, Manfredi III of Chiaramonte obtained the lordship of Mussomeli from King Frederick. He began building the castle and the nearby village, thereby expanding the primitive nucleus of dwellings [Scozzari 1906; Sorge 1916].

The castle is unique in plan and elevation as it adapts to the morphology of the rock on which it stands, with perimeter walls encompassing the stables. Due to its historical, morphological, stylistic and natural features, it has been the subject of numerous studies in recent years by both national and international research groups on the subjects of digitisation and virtual fruition. In 2017, the University of Palermo conducted experimentation with computing technologies aimed at the valorization of cultural heritage. The 3D model of the castle and its surroundings was obtained through SfM methodology to acquire a large photographic dataset, including the use of a drone [Scianna, La Guardia 20 I7]. The South University of Florida on the other hand partnered with the municipal administration in 2019 to render the survey available for upload to the university's servers and so promote international awareness of the castle [2].

The present study includes a digital survey of the stables (fig. 2) to document the geometric and dimensional aspects of the space identified as a reception point for visitors and a place for exhibiting and learning about the historical and architectural heritage of the town. The spatial analysis of the environment will be useful for the installation of educational materials and digital and non-digital workshop activities related to the historical, artistic and architectural heritage of the town. Educational panels will illustrate the architecture of the historic centre of Mussomeli through images, drawings and summary texts (fig. 3), including QR codes to access virtual heritage experiences on mobile devices. In addition, entertaining workshop activities (collage, plastic models, painting, and theatre) will be held in the stables and castle rooms, while educational workshops for older age groups are also planned outside the walls, through learning paths (treasure hunts, interviews, illustrations) that lead to the city centre. Workshops in the religious buildings will also be organised for adult groups, with activities related to the sacred heritage and associated local crafts (ceramics, engravings, fabrics).
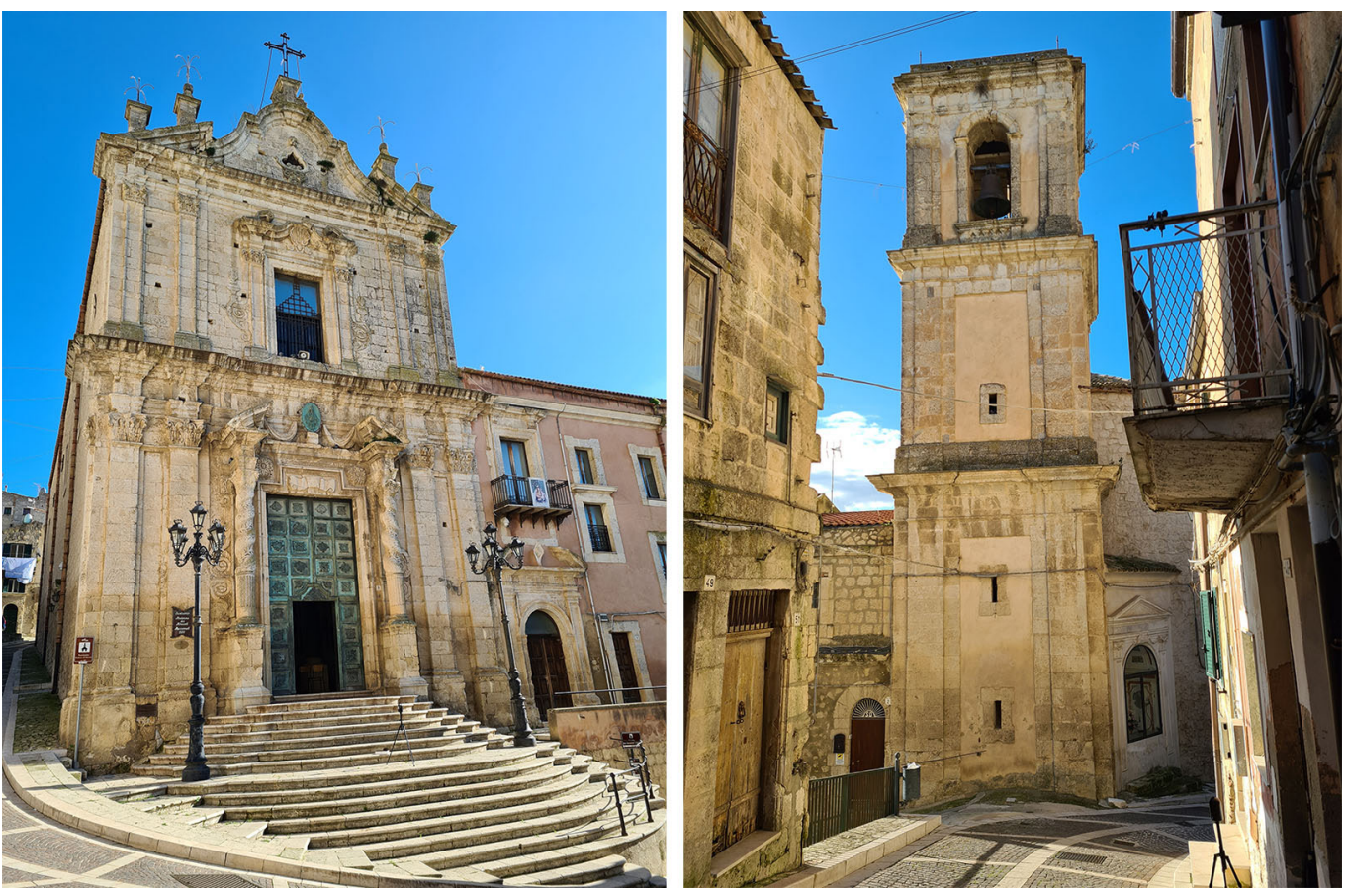
Digital technologies for virtual fruition: the Sanctuary of the Madonna dei Miracoli in Mussomeli and its treasures

The Sanctuary of the Madonna dei Miracoli was chosen for the case study because of its architectural characteristics and precious sacred artistic heritage [Ortiz 20 I 8]. Formerly the Church of San Domenico, the Sanctuary was built in 1750 by an Augustinian monk from Naro and was dedicated to the Madonna for the many graces and miracles she performed. The main façade in late baroque style (fig. 4) has two overlapping architectural orders framed by double angular pilasters and a high tympanum on top. On the axis of the access staircase is a large portal with tall spiral columns resting on a pedestal. It has a single nave and a semi-circular apse covered by a hemispherical dome with lunettes. Behind this stands the bell tower, a three-order square tower with a belfry at the top.
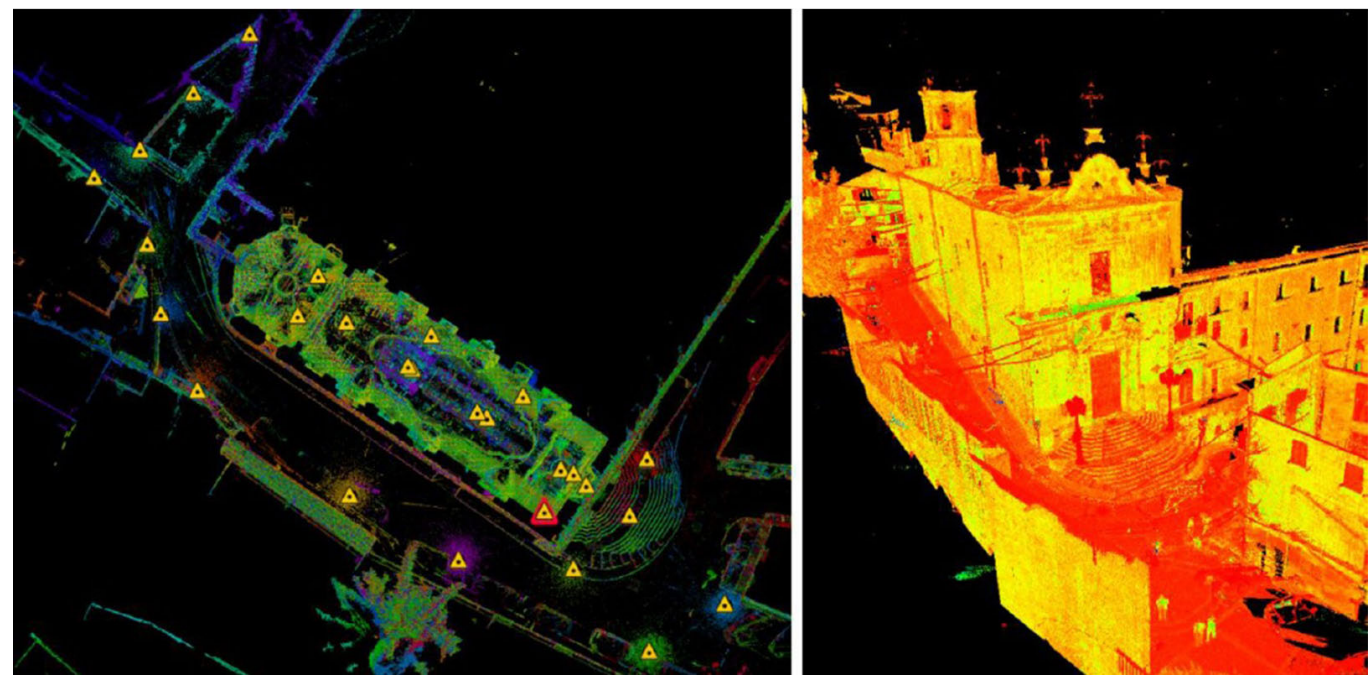

The church contains a rich artistic heritage of a sacred nature [3]: the frescoes by the Dominican Father Domenico Provenzani ( 1736- 1794) from Palma di Montechiaro on the barrel vault with lunettes and on the medallions along the nave and the apse; precious painting by Provenzani and Manno ( 1750 - | 827); marble altars by master marble worker Giuseppe Durante ( $\mid 80 \mathrm{I}$ ); the Madonna, the paralytic and the angel sculptures made in I 876 by Francesco andVincenzo Bianardi, the original sketch of which is kept in the sacristy; the Madonna and Child painted on stone and restored in the I8th century by Provenzani, kept inside the crypt; the jewellery of high Sicilian goldsmith craftsmanship from the late I8th century, ex-voto of the princess of Trabia; the 18th-century carved wooden tabernacle.

The three-dimensional acquisition of the church was performed using the BLK360 laser scanner which, in addition to returning a 3D point cloud, allows $360^{\circ}$ photographs to be taken, corresponding to the station points of the survey. Twenty-seven laser scans were made: 15 for the external survey, 6 for the interior of the church and 6 for the crypt. The numerical model obtained is about 900 million points (fig. 5). Two different approaches using low-cost VR technologies were considered for the virtual fruition of the church: the implementation of the point cloud on an online visualization platform Sketchfab (fig. 6) and a visit based on $360^{\circ}$ panoramic images (fig. 7).

Both experiences allow online fruition with a PC or smartphone, and in VR mode with VR viewers. In the first approach, the user can freely explore the architecture by entering the point cloud and moving around to perceive the real spatiality of the interior.The visualisation platform has already been tested by the research group in other research areas [Santagati 


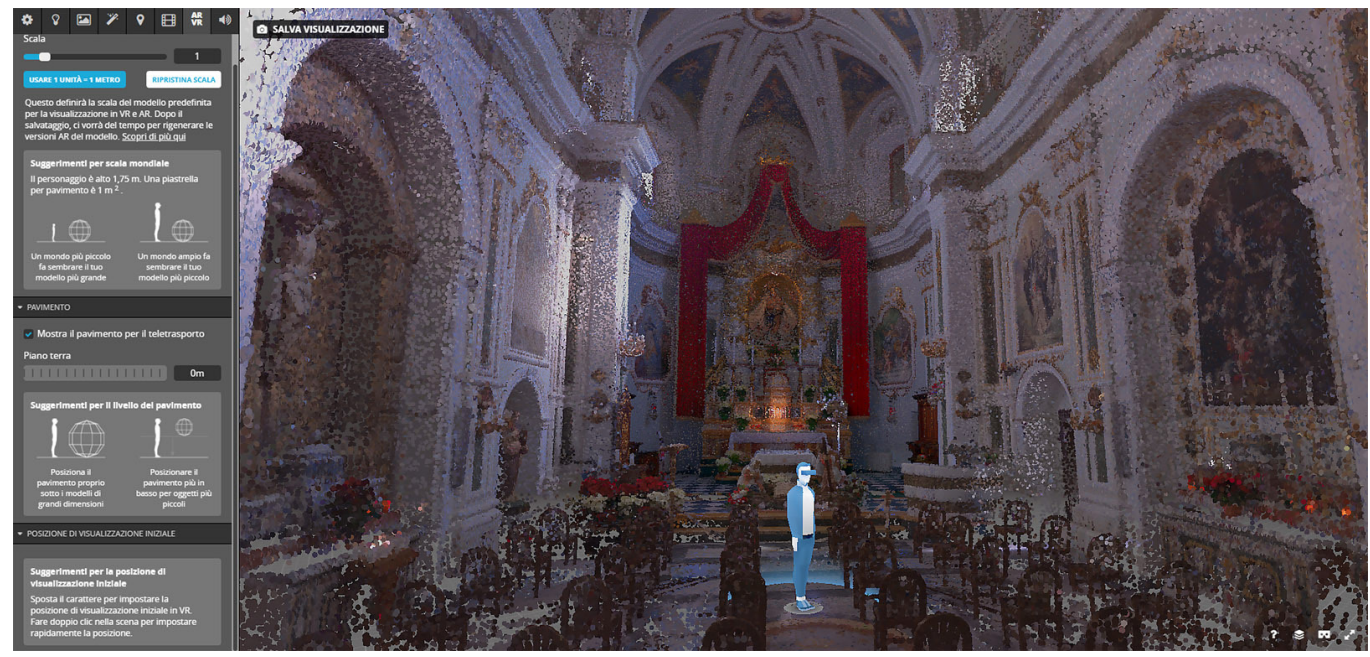

et al. 2020] and was chosen for the ease of loading 3D content, for the direct access to social networks, and for the possibility of including short descriptions. The virtual experience through $360^{\circ}$ photographs, on the other hand, will allow users to navigate the virtual environment from different and default viewpoints. This virtual visit can accommodate multimedia content that might further encourage real visits to the sanctuary. Both experiences can be accessed through the QR-code embedded in the exhibition panels.

Inside the castle stables, users will be presented with an overview of Mussomeli from which they can identify places of interest. They will be drawn into an immersive experience that should also raise interest in the artworks housed within the architecture thanks to the inclusion of interactive objects such as 3D models, images, texts, audio and video. Among these, the Tabernacle and the roughed-out sculpture of the Madonna of the Miracles have been surveyed using SfM techniques to produce polygonal models that can be viewed from any angle and the morphological and descriptive characteristics that define them and their significance can be appreciated (fig. 8). The intention is to digitise the entire artistic heritage for visitors to enjoy, including items not currently being exhibited. In addition, all the frescoes that embellish the interior of the Sanctuary will be captured using the SfM methodology, so that they can be visualised and narrated during virtual tours.

Santuario della Madonna dei Miracoli, Mussomeli (CL)

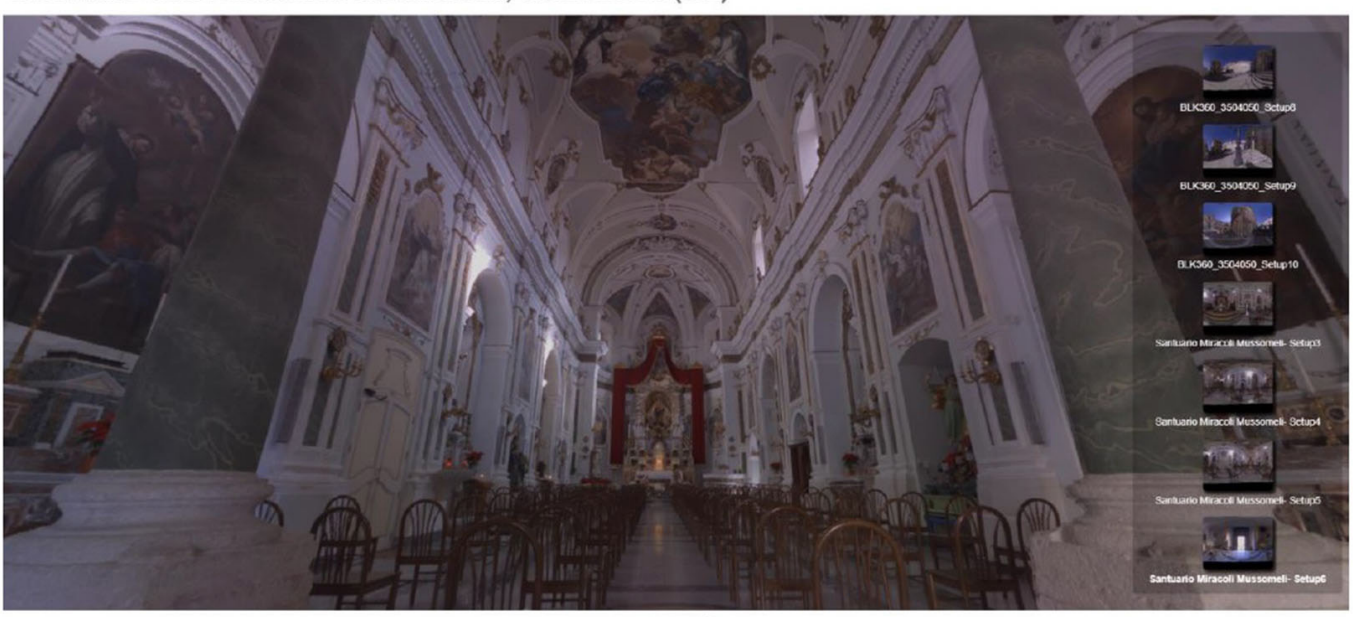

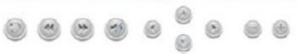




\section{Conclusions and future developments}

This study proposes educational practices for the appreciation and protection of cultural heritage through digital technologies that are more appealing to younger generations, and to reduce distances in spatial and sociocultural terms [4].The aim is to give the user or student control of the scene and thereby encourage involvement and participation [5], as well as the sharing of common cultural heritage through widespread civic awareness. The research in progress will be applied to other heritage sites around the country to create 'open-air museums' that can be visited on site or through virtual tours. Schools shall be involved in order to develop synergies with educational programmes, with a participatory process that allows individuals to orchestrate their own experience of the digital and non-digital works displayed in the stables, in the churches and on the web [Pinna 20 I0].
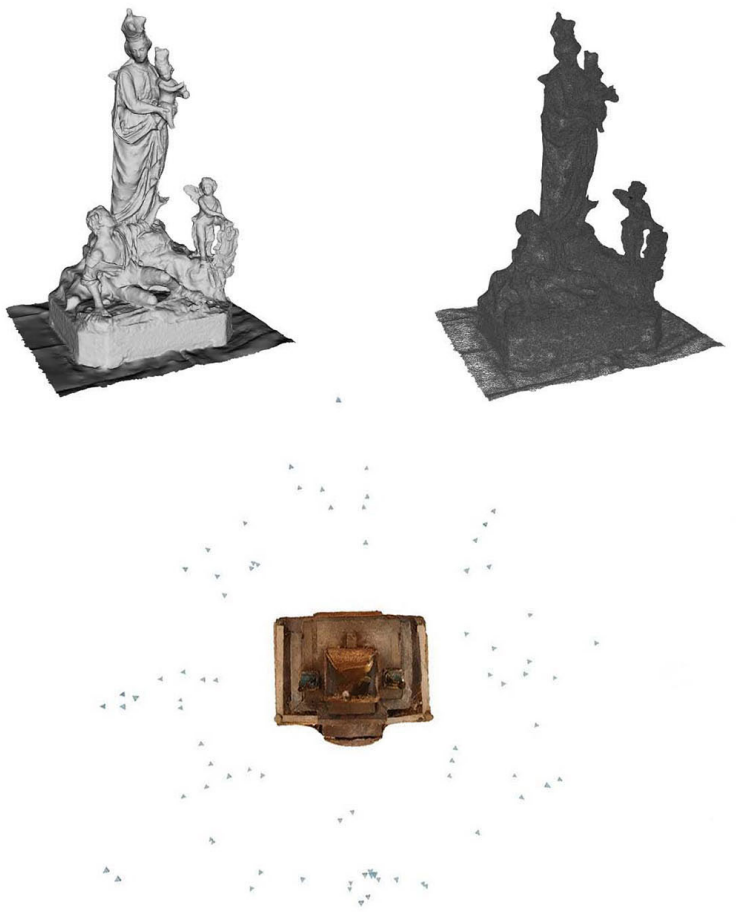
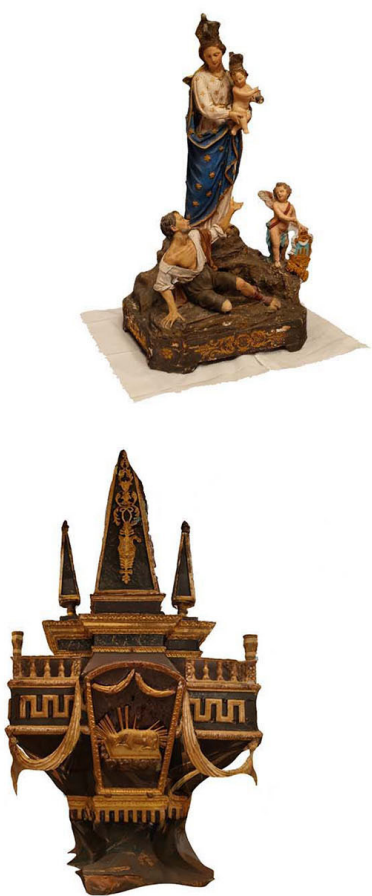

Fig. 8. Above, polygonal model of the roughed out of the sculpture of the Madonna dei Miraco viewed in shaded, wireframe and textured mode; below, polygonal model with dataset of textured mode.

\section{Credits}

Mariateresa Galizia contributed to sections "Introduction", "Methodology" and "Conclusions and future developments". Graziana D'Agostino contributed to sections "The case study" and "Digital technologies for virtual fruition: the Sanctuary of the Madonna dei Miracoli in Mussomeli and its treasures". Giuseppe Maria Spera and Andrés Payà Rico contributed to section "The educational role of Mussomeli's architectural and artistic religious heritage". Giuseppe Maria Spera contributed to section "The castle of Mussomeli and its stables: the educational role of the architectural/artistic heritage between real and virtual fruition".

\section{Notes}

[I] The most representative names in this educational perspective are: Rousseau, Pestalozzi, Froebel, Kerschensteiner, Freinet, Dewey, Baden Powell.

[2] Professor Michael Decker and his collaborators John Northrop, PHD, and Rebekah McLaughlin, PHD Master, from the University of South Florida in Tampa (Florida), Director of IDEx (Institute for Digital Exploration), together with Professor Davide Tanasi from the University of Catania and PhD Elisa Bonacini, Project Manager for USF's digitization projects in Sicily.

[3] Catalogue of Beni Mobili Ecclesiastici of Diocesi of Caltanissetta.

[4] National Plan for Cultural Heritage Education - MiC 2016-2017.

[5] Convenzione Faro 2005. 


\section{References}

Arcomano V. (20 I0-20II). II valore educativo del patrimonio culturale nell'educazione della persona umana. In CQIA RIVISTA, pp. | - 3. Università degli studi di Bergamo.

Andreassi R., Barausse A., D'Alessio M. (2016). Museo della scuola e dell'educazione popolare: Università degli Studi del Molise, Campobasso, Italia. In Cabás, I6, pp. I43-167.

Balconi B. et al. (20 I7). Ciudadanía, sostenibilidad y patrimonio: un análisis curricular. Educación para la ciudadanía entre escuela y territorio en Italia: currículo formal y prácticas didácticas. In R. Martínez Medina, R. García Moris, CR. García Ruiz (Eds.). Investigación en didáctica de las ciencias sociales. Retos, preguntas y lineas de investigación. Cordova: Università di Cordova, pp. $324-332$.

Bonacini E. (20I I). Nuove tecnologie per la fruizione e valorizzazione del patrimonio culturale. Roma: Aracne Editrice.

Bonacini E. (2020). I musei e lo storytelling digitale. Roma: Aracne editore.

Borghi B. (20 I 6). Educación patrimonial en Italia: identidad y ciudadanía. In S. Molina, N. Llonch, T. Martínez Gil (Eds.). Identidad, ciudadanía y patrimonio: educazione storica del XXI secolo, pp. 39-62.Gijón: Edizioni Trea.

Bortolotti A., Calidoni M., Mascheroni S. (2008). Per l'educazione al patrimonio culturale. 22 tesi. Milano: Franco Angeli.

Galizia M. et al. (2020). Connessioni tra museo/archivi e città: strategie digitali per la valorizzazione e comunicazione del fondo Fichera del Museo della Rappresentazione. In A. Arena et al. (Eds.). Connettere. Un disegno per annodare e tessere. Atti del, $42^{\circ}$ convegno UID, pp. 2224-224I. Milano: Franco Angeli.

Grassi C. (20I5). Il Museo tra storia, cultura e didattica. Funzione educativa e ruolo sociale. Pisa: ETS.

Martínez Gil T. (20|4). El patrimonio religioso y la educación patrimonial: un camino por recorrer. In O. Fontal, A. Ibáñez, L. Martín (Eds.). Reflexionar desde las experiencias: una visión complementaria entre España, Francia y Brasil, pp. I| 85 - I |98. Madrid: Instituto del Patrimonio Culturale Spagnolo.

Martínez Gil T. (20I5). El valor inmaterial del patrimonio religioso en Occidente y su función educativa. In J. Santacana, N. Llonch (Eds.). II patrimonio culturale immateriale e la sua didattica, pp. 96- I03. Gijón: Edizioni Trea.

Martínez Gil T., Santacana J. (20 I 8). Uso didáctico del patrimonio. Patrimonio religioso y humanidades. In Religión y escuela:rivista degli insegnanti di religione spagnoli, n. 321-322, pp. I8-21.

Ortiz C. (20 I8). Patrimonio y educación. El patrimonio artístico y religioso y su aplicación didáctica. In Religión y escuela:rivista degli insegnanti di religione spagnoli, n. 321-322, pp. 30-33.

Payà Rico A. (20 I 4). La gestión educativa del patrimonio cultural. In R. López Martín (Ed.). Educación y entorno territorial de la Universitat de València, pp. 47-52. Valencia: Università di Valencia.

Pinna G. (20I0). La Europa del sur y sus museos: el caso de Italia. In Museos.es: Rivista della Sottodirezione Generale dei Musei Statali Spagnoli, 5-6, pp. 68-83.

Santagati C. et al. (2020). Participatory Approach for the enhancement of architectural archives funds: the experience at Museo Rappresentazione in Catania. In XXIV ISPRS Congress, vol. XLIII-B5-2020, pp. 99- 106.

Scianna A., La Guardia M. (20 17). Problematiche e soluzioni nel rilievo rapido e nella restituzione fotogrammetrica speditiva di beni culturali in contesti ambientali complessi. L'esempio del castello manfredonico di Mussomeli. In Bollettino SIFET n. 4 Sezione Scienze, pp. I-7

Scozzari Sac. G. (1906). Notizie Storiche del Santuario e del Convento di Maria SS. dei Miracoli di Mussomeli. Palermo:Tipografia Sicula Giannone \& Cosentino.

Sorge G. (1916). Mussomeli dall'origine all'abolizione della feudalità, vol. II. pp. 398-404. Catania: Cav. Nicolò Giannotta Editore Libraio della Real Casa.

Spera G.M. (1994). Le Confraternite e le Congregazioni di Mussomeli. Cammarata (AG):Tipolitografia Siculgrafica.

\section{Authors}

Mariateresa Galizia, University of Catania, mgalizia@dau.unict.it

Graziana D’Agostino, University of Catania, graziana.dagostino@unict.it

Andrés Payà Rico, University of Valencia, andres.Paya@uv.es

Giuseppe Maria Spera, University of Valencia, sgiuma@alumni.uv.es

To cite this chapter: Galizia Maria Teresa, D'Agostini Graziana, Payà Rico Andrés, Spira Giuseppe Maria (202I). The Castle of Mussomeli (CL) and its stables: an educational and connecting space between local historical heritage sites. In Arena A., Arena M., Mediati D., Raffa P. (a cura di). Connettere. Un disegno per annodare e tessere. Linguaggi Distanze Tecnologie. Atti del $42^{\circ}$ Convegno Internazionale dei Docenti delle Discipline della Rappresentazione/Connecting. Drawing for weaving relationship. Languages Distances Technologies. Proceedings of the $42^{\text {th }}$ International Conference of Representation Disciplines Teachers. Milano: Franco Angeli, pp. 740-749. 